\title{
Droduction of Andropogon gayanus cv. Planaltina dry matter estimated through NDVI
}

João Lucas Aires Dias ${ }^{1}$

Paulo Alexandre Rodrigues Pereira²

Izaías de Macedo Barros³

Pedro Matheus Barboza Barros 4

Sabino Pereira da Silva Neto 5

\section{Abstract}

Pasture management studies seldom use remote sensing, especially for Andropogon gayanus cv. Planaltina. This work aimed to investigate whether a single-chip digital camera converted into multispectral equipment could measure and perceive differences in the normalized difference vegetation index (NDVI) in Andropogon gayanus cv. Planaltina grass subjected to different doses of nitrogen. In a greenhouse with a randomized block design, the research team subjected the cultivar to 5 different doses of nitrogen (treatments), with four replications. The group compared the NDVI measurements of canopies carried out with a GreenSeeker ${ }^{\circledR}$ HCS-100 active optical sensor and a Canon PowerShot A495 single-chip camera that was converted into a multispectral device by replacing the glass filter that blocks the passage of the infrared by a filter that allows the passage of the red and near infrared wavelengths. Both measurements were correlated with nitrogen doses, stem and leaf blades dry matter and dead material production, and cultivar height. The study concluded that the multispectral camera, as well as the active optical sensor, measured the NDVI and noticed differences in the production of stem, leaf blades and dead material dry matter, and Andropogon gayanus cv. Planaltina plant height when subjected to different doses of nitrogen.

Keywords: Field. Forage dry mass. Precision grazing.

\section{Introduction}

Brazil stands out in the world agribusiness as one of the top food producers and exporters. In this context, Brazilian cattle breeding plays an essential role since it has the second largest herd in the world. The herd in Brazil has 214.8 million heads that are kept mainly under grazing, in areas that occupy 171.8 million hectares (IBGE, 2017).

1 Universidade Federal do Tocantins, Campus Gurupi. Graduando curso de Engenharia Florestal. jlucas.florestal@gmail.com. Rua 18A entre as avenidas Rio Branco e Guaporé, Gurupi-TO, 77410350.

2 Universidade Federal do Tocantins, Campus Gurupi. Graduando curso de Agronomia. rodriguespereira23@gmail.com.

3 Universidade Federal do Tocantins, Campus Gurupi. Graduando curso de Agronomia. izaias_macedo11@hotmail.com.

4 Universidade Federal de Viçosa, Campus Viçosa. Graduando curso de Agronomia. pedrogpi12@gmail.com.

5 Instituto Federal de Ciência e Tecnologia do Tocantins, Campus Gurupi. Professor doutor. sabino.pereira@ifto.edu.br. 
The cattle in Brazil have native and cultivated pastures as their primary food source. Farmers use estimates of available grass biomass to determine stocking rates for grazing animals (SANTOS et al., 2008). This prediction is usually performed by sampling the grass, in a chart with a known area. In this sample, farmers determine the availability of dry matter, which will be the reference for forage supply estimates in the entire pasture (DEMINICIS, 2015), and, based on it, they adjust the stocking rate.

New practices and technologies used mainly in precision agriculture are being adopted to monitor pasture biomass; among them, the use of active optical sensors for spectral reflectance of the forage canopy to estimate the pasture productivity stands out (SENA JÚNIOR et al., 2007). Those sensors use the normalized difference vegetation index (NDVI) as an indirect measure of forage supply.

The emergence and development of sensors allowed for higher capacity for data collection in the field, as they neither perform destructive sampling nor have high costs for an extended period. Besides the active optical sensors, there are passive sensors, such as multispectral cameras that can detect the NDVI of the cultures as well (FONSECA et al., 2015).

The main advantage of the multispectral cameras, if compared to the active optical sensors, is the ability to map the horizontal variability of the dry matter supply in the pasture, since these can be loaded in unmanned aerial vehicles (UAVs). This characterization allows us to distinguish the levels of biomass supply of the pasture in the horizontal plane adequately and, consequently, enables us to predict the patterns of displacement and performance of animals in grazing.

Cameras with two or more chips that capture the different wavelengths can obtain the NDVI measurements that allow us to calculate the index. A drawback is that those cameras have a sophisticated optical design, which increases their purchase value. Therefore, the present study aimed to assess the correlation of the NDVI obtained through a conventional single-chip camera, which operates with a multispectral optical filter, with some structural characteristics such as the leaf and stem of Andropogon gayanus cv. Planaltina as a function of nitrogen doses.

\section{Material and methods}

The experiment was carried out from January 14 to May 19, 2015, in a greenhouse at the Federal Institute of Tocantins, where the research team grew Andropogon gayanus cv. Planaltina grass in polyethylene 5-liter pots without holes, containing washed sand and vermiculite in the proportion of $2: 1 \mathrm{VV}^{-1}$ as substrate. In the establishment phase of the culture, plant thinning was performed periodically so that up to five plants per pot remained (SOUZA et al., 2009).

The experimental design used was completely randomized blocks, with five treatments and four replications. The treatments consisted of five doses of nitrogen in the form of urea, corresponding to $0.0 ; 62.5 ; 125.0 ; 87.5$ and $250.0 \mathrm{mg} \mathrm{dm}^{-3}$, based on the capacity of the pots and the substrate proportion, divided into four applications, with an interval of 7 days between applications. Apart from the five treatments, during sowing, all pots were fertilized with a single dose of $200 \mathrm{mg} \mathrm{dm}^{-3}$ of phosphorus, receiving simple superphosphate as a source, and the first application of nitrogen. One week after the sowing, $300 \mathrm{mg} \mathrm{dm}^{-3}$ of potassium in the form of potassium chloride and $2.25 \mathrm{mg} \mathrm{dm}^{-3}$ of domilitic limestone per pot were applied.

On February 24, 2015, 42 days after the plants emerged, the team cut it uniformly at $10 \mathrm{~cm}$ from the ground. The effects of nitrogen doses and NDVI values on the grass dry matter production 
were studied during three successive cuts: March 24, April 21, and May 19, 2015, with a 28-day interval between each cut. All plant materials collected in these cuts were weighed and placed to dry in a forced air convection oven, at $65^{\circ} \mathrm{C}$, until reaching constant weight.

The normalized difference vegetation index (NDVI) was used to analyze the spectral reflectance of the forage canopy (BRANDÃO et al., 2005). NDVI data were collected at 0.60m high from the top of the grass canopy. The data was obtained with a Canon ${ }^{\circledR}$ Powershot A495 10-megapixel camera, fixed on a metal structure pole. We converted the original camera into a multispectral camera by replacing the glass filter that blocks the passage of the infrared wavelength by a Schott ${ }^{\circledR}$ bg3 glass filter, allowing the passage of the red and near-infrared wavelengths. The images of the canopies of the grasses were processed and converted into images that inform the NDVI value. Therefore, the program ImageJ (image processing and analysis in Java), which converts the images to colors at gray values was used, determining the NDVI through coloring. The spectral reflectance measurements were obtained in the same periods, between 9 a.m. and noon, thus minimizing the effect of changes related to the daylight period.

To verify the efficiency of the multispectral camera to analyze the spectral reflectance, the research team used an active optical sensor GreenSeeker ${ }^{\circledR}$ model HCS-100, which has two lightemitting diodes (LED) that emit active radiation in two wavelengths centered in the red (660nm) and near-infrared (770nm), with a $25 \mathrm{~nm}$ spectral width, to measure the NDVI. This equipment generates NDVI values that are automatically calculated through Equation 1:

$$
N D V I=\frac{N I R-R E D}{N I R+R E D}
$$

At which, NIR is the reflectance in near-infrared, and RED is the reflectance in red.

According to Cardoso (2014), the NDVI principle is related to the absorption of radiation in the red spectral region by chlorophylls existing in plant cells and to the scattering or reflectance by the leaves of radiation in the near-infrared region.

After the periodic collections, the data were subjected to analysis of variance and regression to verify the significance of the effect of nitrogen doses on NDVI values. The regression equation was chosen based on the coefficient of determination $\left(R^{2}\right)$, the significance of the regression and its coefficients, tested at $1 \%$ and $5 \%$ probability level. The data of the structural characteristics of the Andropogon gayanus cv. Planaltina were submitted to a simple correlation study through the Pearson test at $5 \%$ and $1 \%$ probability between the NDVI values of the multispectral camera and the active optical sensor.

\section{Results and discussion}

The regression analysis of the leaf blade dry matter production (MSLF) and plant height of the Andropogon gayanus cv. Planaltina shows that the nitrogen $(\mathrm{N})$ changed those productive variables, which adjusted to the quadratic model, and those equations had regression coefficients of 0.96 and 0.98 , respectively (Figure 1 ). 
Figure 1 - Leaf blade dry matter production - MSLF (1a) and plant height (1b) of Andropogon gayanus cv. Planaltina as a function of nitrogen doses. Significance of regression at $1 \%\left(^{* *}\right)$ and $5 \%\left(^{*}\right)$ probability level.

MSLF

(a)

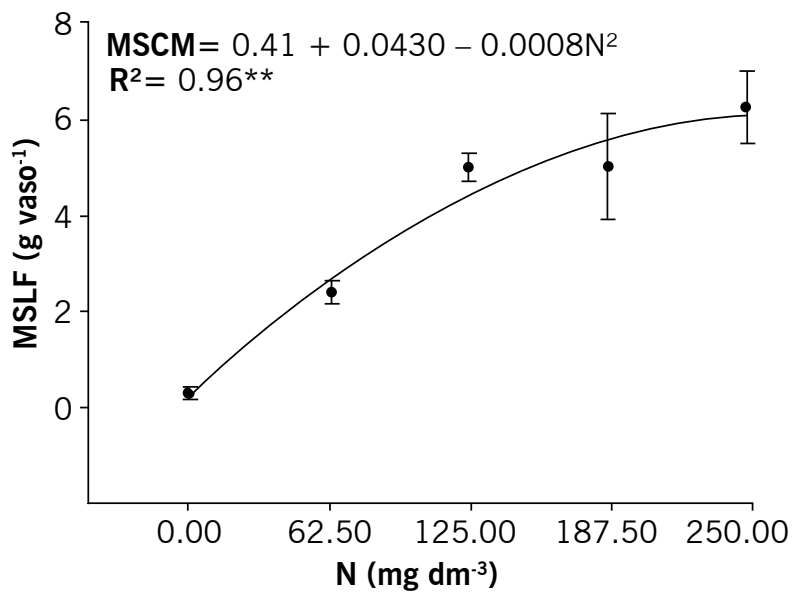

Height

(b)

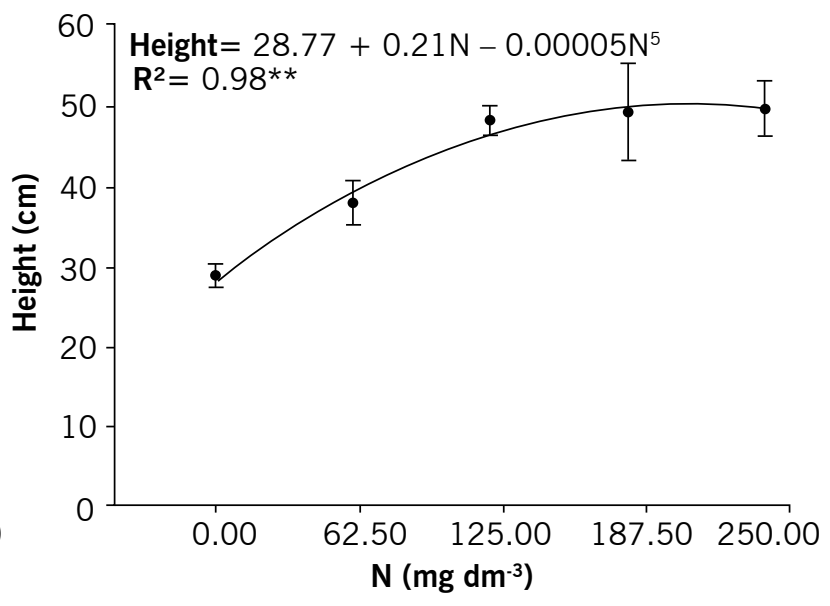

Source: Elaborated by the authors (2019).

The production of stem dry matter (MSCM) and dead material (MSMM) adjusted to the linear model with coefficients of determination equal to 0.86 and 0.61 , respectively (Figure 2 ).

Figure 2 - Production of stem dry matter - MSCM (2a) and dead material - MSMM (2b) of Andropogon gayanus cv. Planaltina as a function of nitrogen doses. Significance of regression at $1 \%\left({ }^{* *}\right)$ and $5 \%(*)$ probability level.

MSMM

(a)

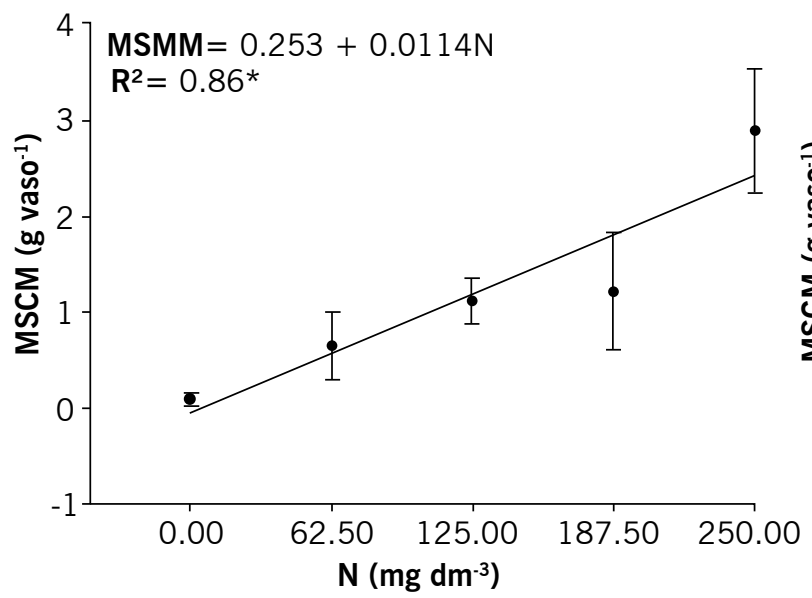

MSMM

(b)

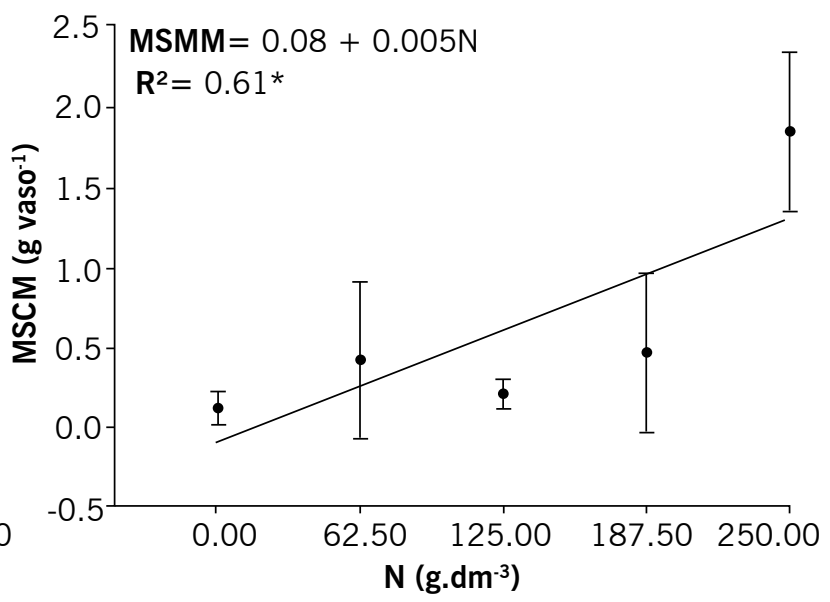

Source: Elaborated by the authors (2019).

The nitrogen fertilization positively influences the production of leaf and stem dry matter of the Andropogon grass (MAGALHÃES et al., 2002). Simões et al. (2015) observed that the dry matter of Tifton grass was influenced by nitrogen fertilization, presenting an equation according to a quadratic model. 
The results of the regression analysis show an effect of $\mathrm{N}$ doses on the spectral characteristics of Andropogon gayanus cv. Planaltina (Figure 3).

Figure 3 - Normalized difference vegetation index - NDVI obtained by an active optical sensor (3a) and a multispectral camera (3b) of the canopy of Andropogon gayanus cv. Planaltina as a function of nitrogen doses. Significance of regression at $1 \%\left(^{* *}\right)$ and $5 \%\left(^{*}\right)$ probability level.

Sensor

(a)

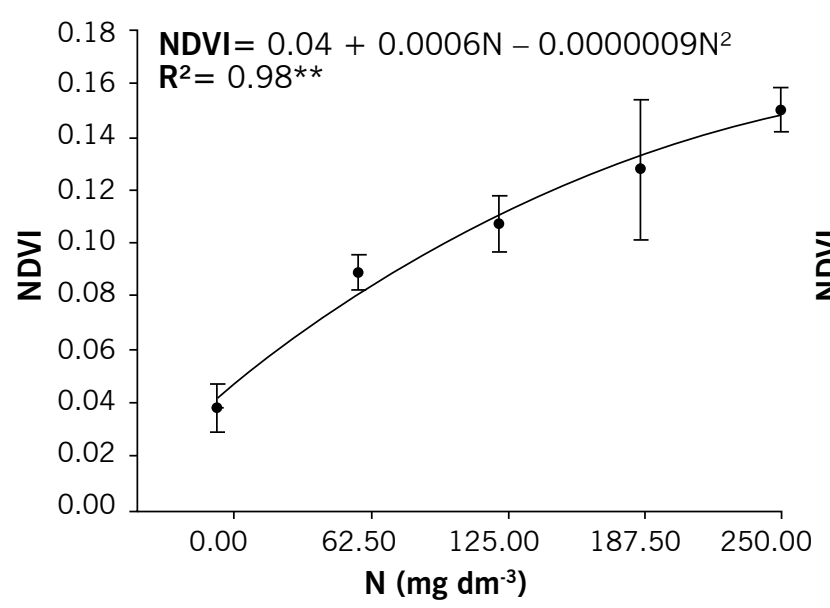

Camera

(b)

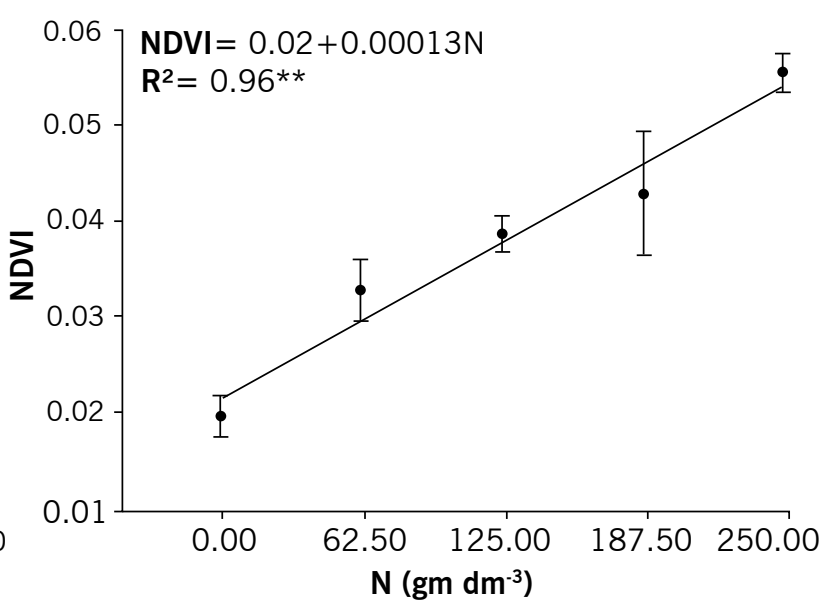

Source: Elaborated by the authors (2019).

The study shows that the spectral response alters with the variation of the biomass (FONSECA et al., 2002), because chlorophyll increases when $\mathrm{N}$ is applied to the plant. Therefore, the absorption of radiation in the region of the visible spectrum is greater, making NDVI to increase (READ et al., 2003). Thus, those spectral changes were detected by both the active optical sensor and the multispectral camera.

In conclusion, this study revealed the possibility of using those technologies that can gradually replace or complement traditional methods to monitor the nitrogen status of forage plants. Furthermore, it can define the best time for nitrogen application for tropical forage grasses, because nitrogen deficiency changes the development and composition of plant leaves and, indirectly, alters the spectral distribution of the radiation reflected by the leaves of deficient plants (TARPLEY et al., 2000).

The regression equations indicate that, although the application of $\mathrm{N}$ influences the spectral responses of the canopies of the Planaltina de Andropogon gayanus cultivar, they showed different mathematical behaviors regarding the methods to obtain the NDVI values (FIGURE 2). Thus, when the active optical sensor was used, the NDVI values adjusted to the quadratic mathematical model, with the coefficient of determination equal to 0.98 . The NDVI responses of the converted multispectral camera, on the other hand, showed linear mathematical behavior and regression coefficient equal to 0.96. However, those two methods have a high correlation between the NDVI values of the plant canopies under investigation (Figure 4). 
Figure 4 - Correlation between measures of the normalized difference vegetation index - NDVI obtained by an active optical sensor and multispectral camera of the Andropogon gayanus cv. Planaltina canopies.

NDVI

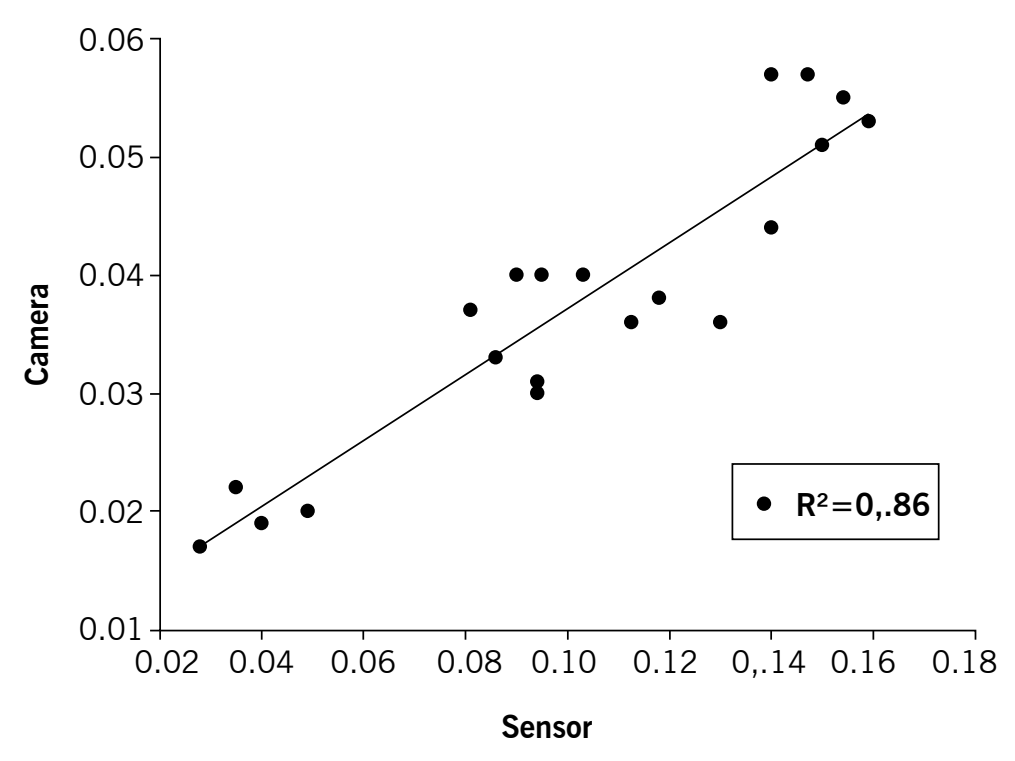

Source: Elaborated by the authors (2019).

The optical sensor is a device already established in the market. We can see that the multispectral camera values approached the optical sensor values (Figure 4), showing the camera's ability to observe reflected spectra. In this sense, we suggest that the NDVI values obtained by the camera can assist in the spatial and temporal monitoring of pastures.

Within the pasture management techniques, animal load and stocking rate adjustments are essential tools to settle the defoliation intensity that the pastures will suffer during animal grazing. Therefore, several factors must be considered: animal category, area size, number of hectares of pasture, available forage, grazing method, among others (CARVALHO et al., 2008). Farmers use estimates of available grass biomass to determine the stocking rates for animal grazing (SANTOS et al., 2008). In this sample, the availability of dry matter that will be the reference for estimates of forage supply across the pasture is determined (DEMINICIS, 2015).

Thus, to validate the ability of the multispectral camera to estimate the structural characteristics of the Andropogon grass using NDVI values, a simple correlation analysis between these variables was performed (Figure 5). The study revealed that the production of leaf blades dry matter (MSLF) and plant height of the Andropogon correlated positively with high values for both devices used to measure the NDVI of forage canopies. 
Figure 5 - Correlation of the normalized difference vegetation index (NDVI) obtained by an active optical sensor and a multispectral camera and the production of leaf blade dry matter - MSLF (5a) and height (5b) of Andropogon gayanus cv. Planaltina plants.

MSLF

(a)

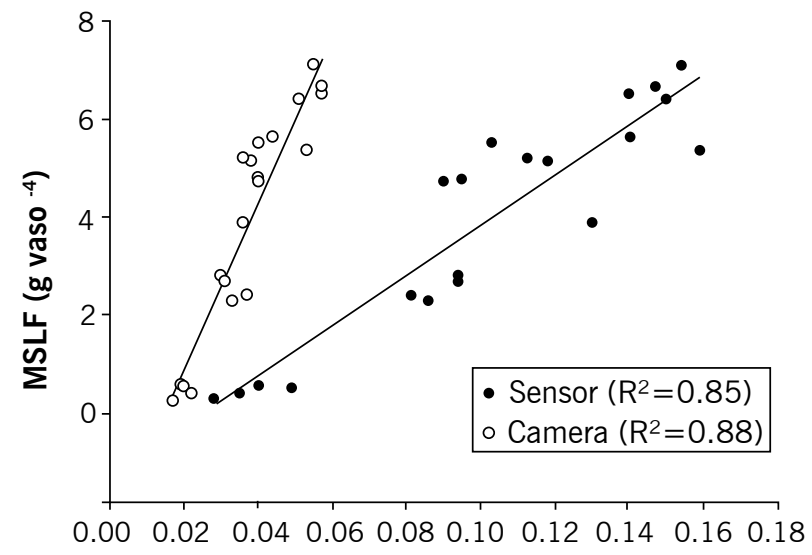

NDVI
Height

(b)

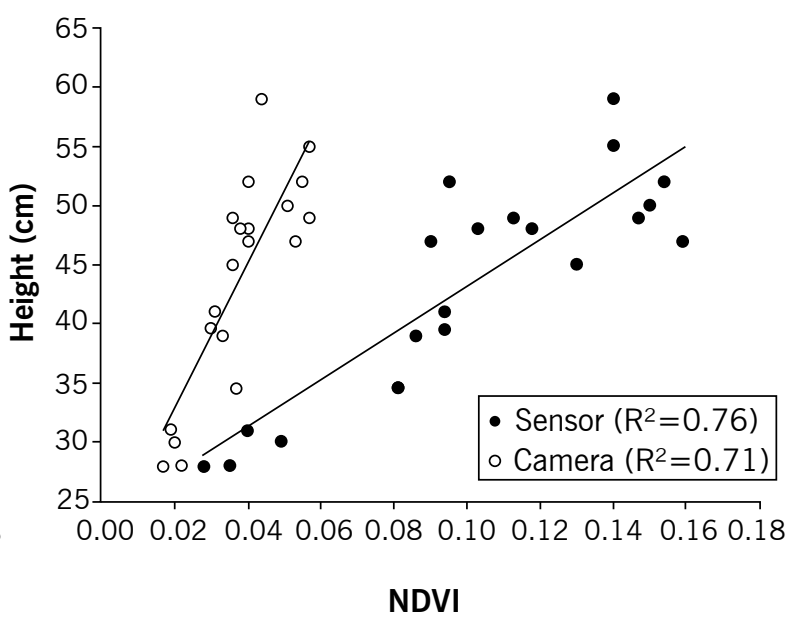

Source: Elaborated by the authors (2019).

The grass leaf blade is the main fraction used to adjust the stocking rate of grazing animals (MARTHA JÚNIOR et al., 2004). Thus, the NDVI values can be used as a pasture management tool, since the knowledge of the availability of the MSLF is essential for the management of grazing animals (ZHAO et al., 2007). Therefore, we observe that NDVI values have excellent potential for indirect estimates of the availability of forage dry matter.

From this perspective, the study's responses indicate that plant height can also be estimated through NDVI values. Typically, the height variable is used to determine pasture management practices such as adjusting animal load or even the moment of entry and exit of animals from a grazing area (MACHADO; KICHEL, 2004).

Regarding the stem dry matter variable (MSCM), a significant and positive correlation was also observed (FIGURE 6). The availability of the stem fraction, as well as leaves and dead material, has a significant variation in a pasture, which generates changes in the quality of the animals' diet since this morphological component is less digestible. 
Figure 6 - Correlation of the normalized difference vegetation index - NDVI obtained by an active optical sensor and a multispectral camera and the production of stem dry matter - MSCM of Andropogon gayanus cv. Planaltina plants.

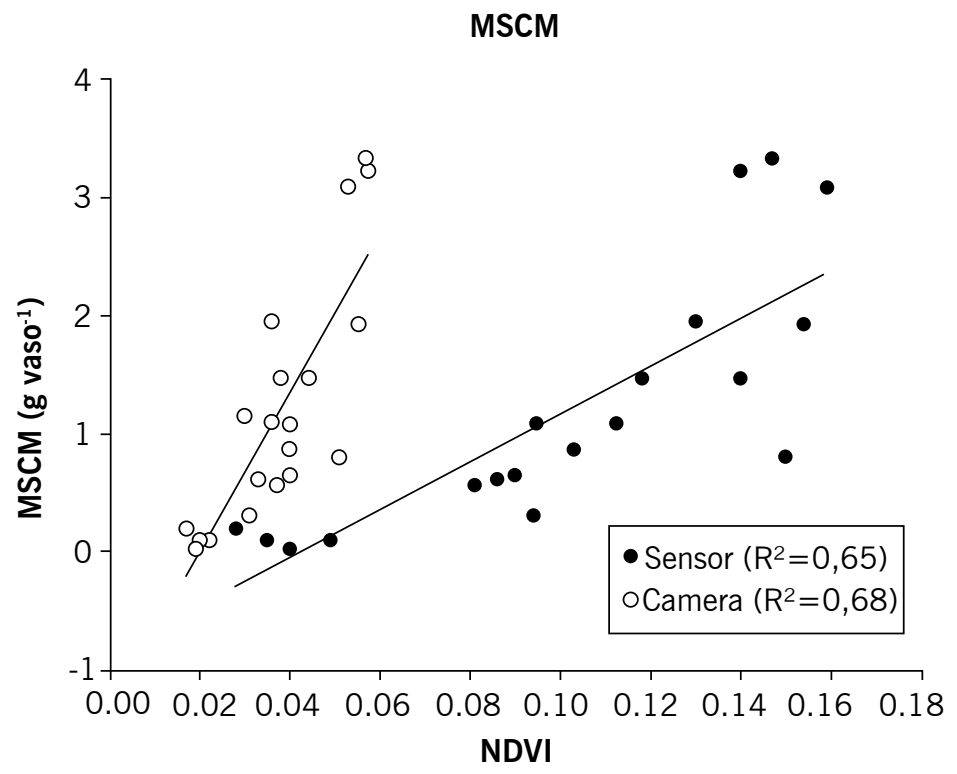

Source: Elaborated by the authors (2019).

Thus, the NDVI can detect variations in the availability of stem dry matter, which helps the pasture manager to adopt actions that minimize changes in the diet quality of grazing animals.

The dry matter of dead material presented the lowest coefficient of correlation (FIGURE 7), which was an expected result, considering that the leaves that have grown old are at the base of the grass.

Figure 7 - Correlation of the normalized difference vegetation index - NDV obtained by an active optical sensor and a multispectral camera and the production of dead dry matter - MSCM of Andropogon gayanus cv. Planaltina plants.

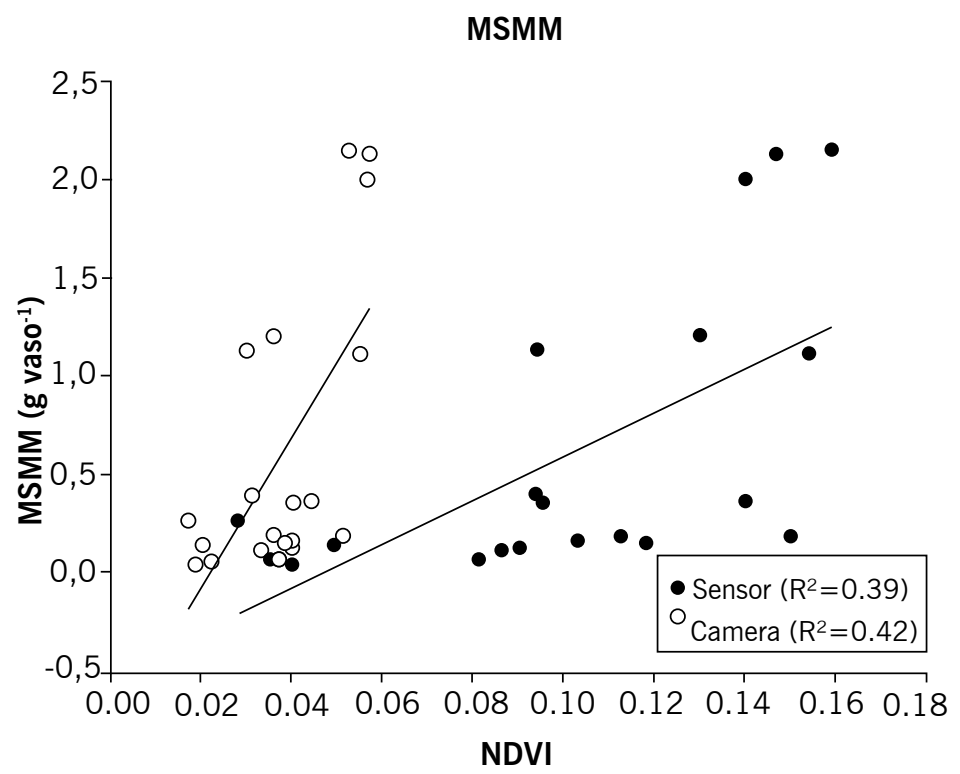

Source: Elaborated by the authors (2019). 
Silva Jr. et al. (2008) found that the dry matter production of the Urochloa decumbens Stapf. correlated positively with the NDVI values obtained by spectral cameras. Abrahão et al. (2009) also observed a positive correlation between NDVI and dry matter production in Tanzania grass. The active optical sensor also shows significant correlations between the NDVI and pasture productivity in terms of green or dry matter (SERRANO et al., 2016).

However, the study revealed that there is a difference in the graphs' prediction when the data are collected through the multispectral camera and the active optical sensor. Such data variation may bring doubts to the producer when the multispectral camera is indicated to estimate the biomass in Andropogon gayanus cv. Planaltina grass pastures.

The differences between the NDVI values of both the optical sensor and the camera are due to some technical characteristics such as the difference in the area of coverage, light available when capturing data, and the area to be studied. The optical sensor captures the physical characteristics of the plant because it represents the capture area in the shape of an ellipse and has its radiation, regardless of the use of sunlight to obtain data when collecting reflectance. The multispectral camera, on the other hand, captures the soil around the plant and depends on the sunlight at the time the image is taken.

Therefore, it is possible to generate an availability model of grass dry matter through NDVI readings, both from the multispectral camera and the active optical sensor, under different doses of $\mathrm{N}$.

\section{Conclusions}

The NDVI values captured by a multispectral camera correlate with the structural characteristics of the Andropogon gayanus cv. Planaltina. Therefore, using the NDVI values of the canopy in Andropogon grass pasture can help pasture management.

The multispectral camera measured the normalized difference vegetation index (NDVI) and showed differences in the production of stem, leaf blades, and dead material dry matter, and the plant height of Andropogon gayanus cv. Planaltina when subjected to different doses of nitrogen.

\section{Produção de matéria seca do capim Andropogon gayanus cv. Planaltina estimadas por meio do NDVI}

\section{Resumo}

A utilização do sensoriamento remoto em estudos de manejo de pastagens é escassa, especialmente para Andropogon gayanus cv. Planaltina. 0 objetivo do trabalho foi averiguar se uma câmera digital de chip único, convertida em equipamento multiespectral, seria capaz de medir e de perceber diferenças no índice vegetativo da diferença normalizada (NDVI) no capim Andropogon gayanus cv. Planaltina submetida a diferentes doses de nitrogênio. Conduziu-se um experimento em casa de vegetação com delineamento em blocos casualizados, submetendo o cultivar a 5 diferentes doses de nitrogênio (tratamentos), com 4 repetições. Medições de NDVI foram realizadas sobre os dosséis utilizando um sensor óptico ativo GreenSeeker ${ }^{\circledR}$ modelo HCS-100 e comparadas com as medições da câmera Canon PowerShot A495 de chip único, convertida em equipamento multiespectral por meio da remoção do filtro de vidro que bloqueia a passagem do comprimento de onda do infravermelho. Em seu lugar, inseriu-se o filtro que permite a passagem dos comprimentos de ondas do vermelho e infravermelho próximo. As medições de ambos os equipamentos foram correlacionadas com as doses de nitrogênio, 
produção de matéria seca do colmo, lâminas foliares, material morto e altura do cultivar. Semelhante ao sensor óptico ativo, concluiu-se que a câmera multiespectral mediu o NDVI e percebeu diferenças na produção de matéria seca do colmo, de lâminas foliares e de material morto e da altura de plantas do Andropogon gayanus cv. Planaltina quando submetidas a diferentes doses de nitrogênio.

Palavras-chave: Campo. Massa seca de forragem. Pastejo de precisão.

\section{References}

ABRAHÃO, S. A.; PINTO, F. A. C.; QUEIROZ, D. M.; SANTOS, N. T. S.; GLERIANI, J. M.; ALVES, E. A. Índices de vegetação de base espectral para discriminar doses de nitrogênio em capim-tanzânia. Revista Brasileira de Zootecnia, v. 38, n. 9, p. 1637-1644, 2009.

BRANDÃO, Z. N.; BEZERRA, M. V. C.; FREIRE, E. C.; SILVA B. B. Determinação de Índices de Vegetação usando Imagens de Satélite para uso em Agricultura de Precisão. In: Congresso Brasileiro de Algodão, 5. CBA, Salvador, BA, 2005. Anais... Campina Grande: CNPA, 2005. CD-ROM On-line.

CARDOSO, R. S.; AMORIM, M. C. C. T. Avaliação dos índices NDVI, NBDI e NDWI como ferramentas ao mapeamento do uso e cobertura da terra. In: Congresso Brasileiro de Geógrafos, 7, Vitória, ES, 2014.

CARVAlHO, R. C. R.; ATHAYDE, A. A. R.; VAlerianO, A. R.; MedeiROS, L. T.; PINTO, J. C. Método de determinação da disponibilidade de forragem. Ciência et Praxis, Passos, MG, v. 1, n. 2, p. 7-10, 2008.

DEMINICIS, B. B. Novas tecnologias aplicadas na produção e qualidade de forragens. In: KUHN, O. J.; NUNES, R. V.; STANGARLIN, J. R.; RAMPIM, L.; FEY, R.; COSTA, N. V.; COSTA, P. B.; GUIMARÃES, V. F.; ZAMBOM, M. A. Ciências agrárias: tecnologias e perspectivas. Marechal Cândido Rondon: Editora Unioeste, 2015. p. 247-256.

FONSECA, C. R.; DIAS, J. L. A.; SILVA, T. L.; BARROS, P. M. B.; SILVA NETO, S. P. Câmera multiespectral discrimina alterações espectrais do dossel do capim-Marandu em função da adubação nitrogenada. In: Reunião anual da Sociedade Brasiliera para o Progresso da Ciência. Anais... São Carlos, SP. SBPC, 2015.

FONSECA, E. L.; ROSA, L. M. G.; FONTANA, D. C. Caracterização espectral de Paspalum notatum em diferentes níveis de adubação nitrogenada. Pesquisa Agropecuária Brasileira, v. 37, n. 3, p. 365-371, 2002.

IBGE: Pesquisa pecuária municipal. Efetivo do rebanho bovino em 2016. Disponível em: <http://www.sidra.ibge.gov.br/bda/pecua >. Acesso em 13 ago. 2016.

MACHADO, L. A. Z.; KICHEL, A. N. Ajuste de lotação no manejo de pastagens. Dourados, MT: Embrapa Gado de Corte, 2004. 55 p.

MAGALHÃES, R. T. de; OLIVEIRA, I. P. de; KLIEMANN, H. J. Relações da produção de massa seca e as quantidades de nutrientes exportados por Brachiaria brizantha em solos sob o manejo pelo sistema “Barreirão". Pesquisa Agropecuária Tropical, v. 32, n. 1, p. 1320, 2002. 
MARTHA JR., G. B.; CORSI, M.; BARIONI, G. L.; VILELA, L. Intensidade de desfolha e produção de forragem do capim-tanzânia irrigado na primavera e no verão. Pesquisa Agropecuária Brasileira, v. 39, n. 9, p. 927-936, 2004.

READ, J. J.; WHALEY, E. L.; TARPLEY, L.; REDDY, R. Evaluation of a hand-held radiometer for field determination of nitrogen status in cotton. In: SCHERPERS, J.; VANTOAI, T. Digital Imaging and Spectral Techniques: Applications to Precision Agriculture and Crop Physiology. American Society of Agronomy Special Publication, n. 66, 2003. p. 177-195.

SANTOS, S. A.; DESBIEZ, A.; ABREU, U. G. P.; CRISPIM, S. M. A. Guia para estimativa da taxa de lotação e pressão de pastejo em pastagens nativas do Pantanal. Corúmba, MS: Embrapa Pantanal, 2008. 26 p.

SENA JUNIOR, D. G.; PINTO, F. A. C.; QUEIROZ, D. M.; AlVES, E. A.; MAGALHÃES, J. R. Influência do solo na identificação de doses de nitrogênio em trigo utilizando classificadores multivariados com base em imagens digitais. SIMPÓSIO BRASILEIRO DE SENSORIAMENTO REMOTO, 13, 21-26 abr. 2007, Anais... Florianópolis, Brasil, INPE, p. 385-392.

SERRANO, J. M.; BARRETO, S.; SHAHIDIAN, S.; SILVA, J. M.; Avaliação do sensor óptico de vegetação $O p t R x^{\circledR}$ na monitorização da variabilidade espacial e temporal de pastagens. Revista de Ciências Agrárias, 2016, v. 39, n. 2, p. 261-280, 2016.

SILVA JUNIOR, M. C.; PINTO, F. A. C.; FONSECA, D. M.; QUEIROZ, D. M.; MACIEL, B. F. Detecção do efeito da adubação nitrogenada em Brachiaria decumbens Stapf. Utilizando um sistema de sensoriamento remoto. Revista. Brasileira de Zootecnia, Viçosa-MG, v. 37, n. 3, p. 411-419, 2008.

SILVA JUNIOR, C. A.; FRANK, T.; RODRIGUES, T. C. S. Discriminação de áreas de soja por meio de imagens EVI/MODIS e análise baseada em geo-objeto. Revista Brasileira de Engenharia Agrícola e Ambiental, v. 18, n. 1, p. 44-53, 2014. DOI: dx.doi.org/10.1590/S1415-43662014000100007.

SIMÕES, C. R.; ROSSIELLO, R. O. P.; GRACIOSA, M. G.; MACHADO, M. L.; SILVA, C. F. Imagens multiespectrais para avaliação de índice de área foliar e massa seca do capim ‘Tifton 85', sob adubação nitrogenada. Ciência Rural, v. 45, n. 4, p. 697-703, 2015.

SOUZA, H. D. F.; ANDRADE, R. P. A.; KARIA, C. T. Seed production of pojucagrass as influenced by crop establishment techniques. Ciência Rural, v. 39, n. 3 Santa Maria, 2009.

TARPLEY, L.; REDDY, K. R.; SASSENRATH-COLE, G. F. Reflectance indices with precision and accuracy in predicting cotton leaf nitrogen concentration. Crop Science, v. 40, n. 6, p.1814-1819, 2000.

ZHAO, D.; STARKS, P. J.; BROWN, M. A.; PHILIPS, W. A.; COLEMAN, S. W. Assessment of forage biomass and quality parameters of bermudagrass using proximal sensing of pasture canopy reflectance. Grassland Science, v. 53, n. 1, p. 39-49, 2007.

Received in: June 22, 2019

Accepted in: October 21, 2019 